\title{
The Protective Role of Green Tea Against Ethanol-mediated Bone Alterations in Adult Male Rabbits: Biochemical, Histological and Morphometrical Study
}

\section{Original Article}

Hazim A. Wahab ${ }^{1,2}$, Ramadan A. Eldamhogy', Nehal S. El-Moukhdem ${ }^{3}$ and Mohammed Abdel-Gabbar ${ }^{4}$

\author{
${ }^{I}$ Department of Histology, Faculty of Medicine, Menofiya University, Shebin Elkom, Egypt \\ ${ }^{2}$ Department of Histology, College of Medicine, Aljouf University (CM-AU), Saudi Arabia \\ ${ }^{3}$ Department of Clinical pathology, CM-AU, Sakaka, Saudi Arabia \\ ${ }^{4}$ Department of Biochemistry, Faculty of science, Beni-Suef University, Beni-Suef, Egypt.
}

\begin{abstract}
Background: Chronic alcohol abuse is a widespread clinical disorder. It leads to bone alterations, mainly osteoporosis. Next to water, tea (green or black) is the most widely consumed beverage in the world. Bone mineral density is affected by several compounds contained in tea extracts.

Aim of the Work: Our work aimed to investigate the effects of alcohol on adult male rabbit's compact bone and the possible protective effect of green tea extract. (GTE)

Material and Methods: Twenty-four young adult male rabbits were used. They were divided into equal 4 groups: normal control, green tea, ethanol (EtOH) and $\mathrm{EtOH}$ - green tea. After 120 days of treatment, all animals were anaesthetized and sacrificed. Blood ethanol and serum ionized calcium (iCa), phosphorus (P) and alkaline phosphatase (ALP) levels were estimated. Serum creatinine, alanine aminotransferase (ALT) and aspartate aminotransferase (AST) activities were estimated to determine renal and hepatic integrity. Femurs of each rabbit were processed for histological and morphometrical study.

Results: Chronic alcohol ingestion resulted in a non_significant decrease in serum iCa level and a significant decrease in serum ALP activity. EtOH -treated rabbits did not differ from the controls in mean serum levels of ALT, AST, creatinine or phosphorus. Bone sections from EtOH- treated rabbits revealed multiple areas of degeneration in the thin cartilaginous plate. The trabeculae were thinner, shorter and fewer than those from controls. There was a significant decrease in osteoblast surface and a significant increase in osteoclast surface. Green tea supplementation resulted in marked improving of biochemical, histological and all histomorphometric parameters under investigation.

Conclusion: From the foregoing, dangerous effects of alcohol on the bone became clear. So it is better to restrict its consumption. Natural products as green tea are able to protect against bone deterioration.
\end{abstract}

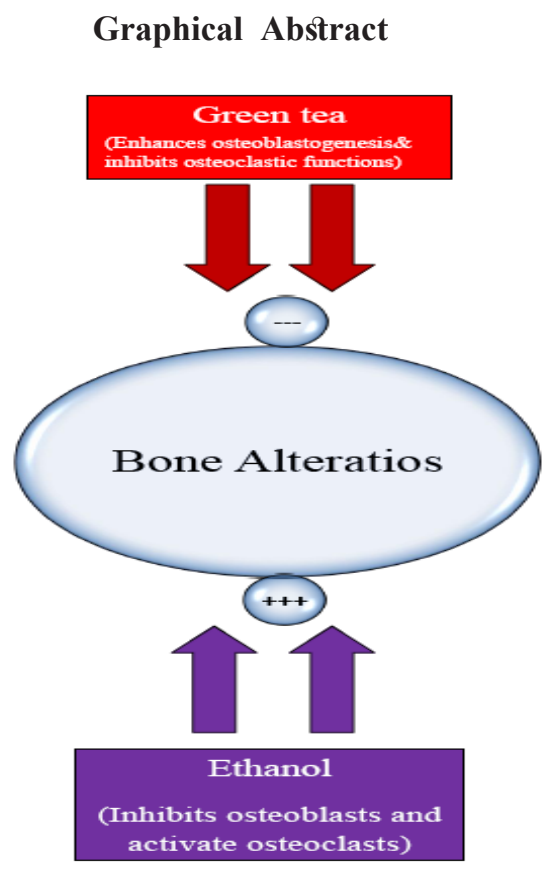


Received: 27 February 2020, Accepted: 11 April 2020

Key Words: Alcohol, bone, green tea, histology.

Corresponding Author: Hazim A.Wahab, MD, Department of Histology, Faculty of Medicine, Menofiya University, Shebin Elkom, Egypt, Department of Histology, College of Medicine, Aljouf University (CM-AU), Sakaka, Saudi Arabia, Tel.: +201023093470, E-mail: haw_1968@hotmail.com

ISSN: 1110-0559, Vol. 44, No.1

\section{INTRODUCTION}

Alcohol is largely consumed in the world. Heavy alcohol consumption has harmful effects on the brain, liver and muscloskeletal system ${ }^{[1]}$. Alcohol consumption markedly increases the risk of osteoporosis, fractures ${ }^{[2]}$ and complications in fracture healing ${ }^{[3,4]}$ mediated apparently via direct effect of alcohol on the bone ${ }^{[5]}$ or indirect effects via altering vitamin D3 and calcium regulating hormones ${ }^{[6,7]}$.

Moderate alcoholic beverages consumption in humans may reduce bone turnover and potentially have harmful effects on the skeleton ${ }^{[8]}$. Epidemiological studies of alcohol abuse and human bone health indicate that chronic heavy alcohol abuse, particularly in young adults, can affect bone health and may increase the risk of development of osteoporosis. Further, research indicates that the effects of heavy alcohol consumption on bone cannot be reversed ${ }^{[9]}$.

Studies on the effects of alcohol on bone have demonstrated inhibition of bone growth, reduced mineral density $^{[10]}$ and reduced bone strength ${ }^{[11]}$. The skeletal changes resulted from ethanol consumption seem to be independent of liver deterioration or calciotropic hormone levels, and there is much reasoning that ethanol acts directly on osteoblastic activity ${ }^{[9]}$. Prenatal ethanol exposure can retard both fetal and postnatal bone growth and can increase the risk of osteoporosis later in life $\mathrm{e}^{[12]}$.

Tea is one of the most widespread drinks in the world ${ }^{[13,14]}$. Depending on the reproducing process, teas can be categorized into three major divisions: 'non-fermented' green tea; 'semi-fermented' oolong tea and 'fermented' red and black teas ${ }^{[15]}$. Green tea is deemed to be a remarkable dietary source of polyphenols, mainly flavonoids. Catechins are the main flavonoids present in green tea ${ }^{[16]}$. Catechins are more abundant in green tea rather than black or oolong teas and have strong antioxidants potentials ${ }^{[13]}$.

Many studies suggest a substantial impact of green tea intake on bone density, cognitive functions, dental health and renal calculi ${ }^{[15,16]}$. Recently, a possible relation between tea consumption and osteoporosis has been proposed ${ }^{[17-19]}$.

Accordingly, we planned this study to investigate the effects of ethanol on adult male rabbit's compact bone and the possible protective effect of green tea extract based on biochemical, histological and morphometrical study.

\section{MATERIAL AND METHODS}

\section{Chemicals and Assay Kits}

Ethyl alcohol 95\% and all high reagent grade chemicals and diagnostic kits which were of high grade level, were purchased from Sigma-Aldrich (St. Louis, MO, USA). Green tea (Camellia sinensis) produced by Shanghai Tea Import and Export Corporation, China, was also used in the study. GTE was made by drenching green tea powder (15 $\mathrm{gm})$ in a liter of boiling water for 5 minutes. The solution was filtered to get GTE, $1.5 \%{ }^{[20]}$. This solution was given to rabbits as the only source of drink.

\section{Animals}

Twenty four young adult male New Zealand White rabbits, 3 month -old, weighing $2-2.4 \mathrm{~kg}$ were used in the study that was accepted by the Institutional Animal Care and Use Committee of Menoufyia University. Throughout the experiment, animals were housed in-groups in separate cages in an adequate temperature and ventilation and allowed standard chow and drink ad-libitum.

\section{Experimental design}

After one-week adaptation period, animals were randomly divided into four equal groups:

Group I (Control group), received distilled water.

Group II (Green tea treated group), received green tea extract $(1.5 \%)$ as the only source of drinking water.

Group III (Ethanol-treated group), received ethanol orally $5 \mathrm{~g} / \mathrm{kg} /$ day, $20 \% \mathrm{w} / \mathrm{v}$ using gastric tube, being weekly adjusted after weighting the rabbits ${ }^{[21]}$.

Group IV (Ethanol and green tea cotreated group), received ethanol orally $5 \mathrm{~g} / \mathrm{kg} / \mathrm{day}, 20 \% \mathrm{w} / \mathrm{v}$ and green tea extract $(1.5 \%)$ as the only source of drinking water.

\section{Duration time}

The experiment continued for 120 days.

\section{Sample Collection, sectioning and staining}

Twenty-four hours after the last dose, rabbits were anaesthetized by ether and blood samples were obtained from orbital venous plexuses by capillary tubes. Samples were measured immediately for ethanol levels. Sera were separated and frozen at $-20^{\circ} \mathrm{C}$ till further biochemical 
measurements then animals were sacrificed and dissected. Femurs of both sides were removed by disarticulation at the knee and hip joints. The soft tissues were dissected away, and the femurs were fixed in $10 \%$ phosphate-buffered formalin for 24 hours, decalcified in $14 \%$ EDTA $^{[22]}$. The specimens were paraffin-embedded and cut into $5-\mu \mathrm{M}$ longitudinal and cross sections from middle of femurs for staining with hematoxylin and eosin (H\&E) for routine histological study ${ }^{[23]}$, periodic acid-Schiff (PAS) for glycoproteins and Alcian blue (1\% Alcian blue in 3\% acetic acid, $\mathrm{pH} 2.5$ ) for acid mucopolysaccharides, Masson's Trichrome (MT), for demonstration of mineralized and unmineralized bone matrix in the bony trabeculae ${ }^{[22]}$.

\section{Biochemical measurements}

Blood ethanol levels were estimated by measuring the ability of alcohol dehydrogenase to form acetaldehyde from blood samples as adviced by the producer (Alcohol Level Kit; Sigma Chemical Co., St. Louis, Missouri, USA). As ethanol has a volatile nature, specimens were kept capped at all times to avoid evaporation ${ }^{[24]}$.

Blood ionized calcium (iCa) was measured using the I-Stat Clinical Analyzer, its performance is not affected by ethanol ${ }^{[25]}$.

Serum alkaline phosphatase (ALP), phosphorus (P), creatinine, alanine aminotransferase (ALT) and aspartate aminotransferase (AST) levels were measured automatically by Integra 800 auto-analyzer, Liver Institute, Menoufia University.

\section{Histomorphometry}

Histomorphometry was done using Leica Qwin 500 image analyzer computer system (England). The system was adjusted to convert the pixels into micrometers. Sections stained with H\&E were used to determine trabecular thickness, separation, and number at metaphyseal end of decalcified sections of femurs of all groups magnified at $40 \mathrm{x}$. From each specimen 10 fields were measured. Using the color detect, the bone trabeculae were covered by a red binary color (Figure 1).

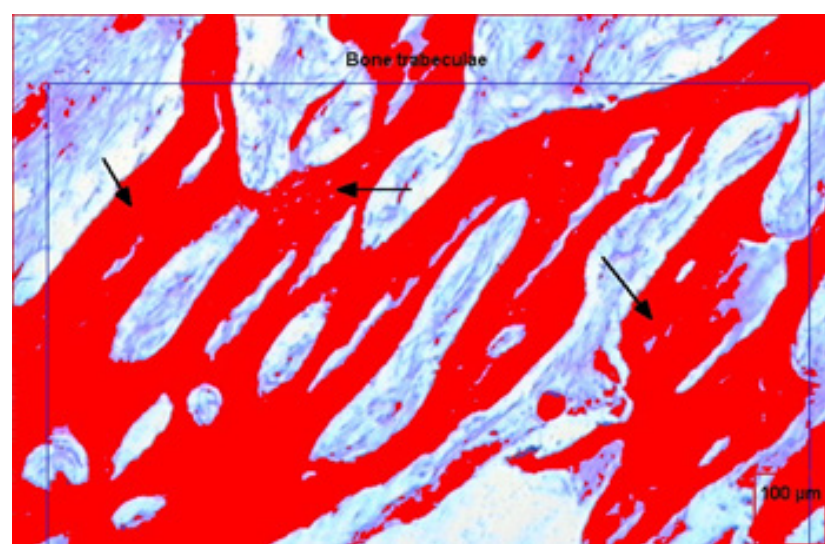

Fig. 1: Bone trabeculae, binary image. (H\&E X 40).

Sections were used to determine total surface of bone (BS), osteoblast surface and osteoclast surface magnified at $100 \mathrm{x}$. Raw data were exported to an excel sheet and derived indices of osteoblast surface (Ob.S/BS), which represents the percentage of the surface of bone covered with osteoblasts and osteoclast surface (Os.C/BS), which represents the percentage of the surface of bone covered with osteoclasts were calculated ${ }^{[21]}$.

\section{Statistical analysis}

Data analyses was done using one-way analysis of variance (ANOVA) using the Tukey post hoc test comparing different groups with the controls. Results were expressed as mean $\pm \mathrm{SD}$. Statistical significance was set at $P$ value $<0.05$. SPSS for Windows (version 16, Chicago, IL, USA) 26 was used in data analysis.

\section{RESULTS}

\section{Biochemical results}

EtOH administration resulted in a non_significant decrease in serum level of ionized calcium and a significant decrease in ALP compared to control and GTtreated groups $(p<0.05)$ with non_significant differences amongst groups I and II . However, supplementation with green tea extract in group IV significantly improved ALP activity $(p<0.05)$.

Ethanol-treated rabbits did not differ from the controls or GT- treated groups regarding to serum levels of phosphorus and creatinine and activities of ALT and AST (Table 1).

\section{Histological and Histochemical results}

\section{(A) Hematoxylin and Eosin-Stained sections}

Longitudinal sections in the lower femoral epiphyseal plate of both control and G.T treated animals showed different stages of bone growth: resting cartilage , proliferation, hypertrophy and calcification zones (Figure 2). Bony trabeculae were long and thick (Figure 3).

Sections of ethanol treated rabbits revealed thinning of the cartilaginous plate with apparent decrease in proliferative and hypertrophic zone. Multiple areas of degeneration affecting the proliferating zone. The developing trabeculae were shorter, thinner and fewer in number than those from control rabbits (Figure 4).

Sections of of group IV, which received ethanol and GT showed that metaphyseal trabeculae became moderate in length, width and number with little areas of degeneration in the epiphyseal plate. The basophilic calcified cartilagenous matrix are well noticed (Figure 5).

Sections of ethanol treated animals showed many osteoclasts in osteolytic cavities. The cells were large, multinucleated, cytoplasm was foamy having many vesicles, brush borders were seen near-by eroded thinned parts of bone (Figure 6).

Transverse section in the diaphysis of the femur of control animals showed many osteons with normal bony architecture (Figure 7) that was lost after ethanol treatment 
with appearance of separated cement lines and multiple osteoporotic cavities (Figure 8).

\section{(B) Alcian Blue (A B) -Stained sections}

Sections of control and G.T treated animals showed dense blue-colored matrix (normal distribution of acid mucopolysaccharides of the matrix) (Figure 9).

There was slight reaction after treatment with ethanol, the matrix of the resting zone appeared turquoise-blue (Figure 10). Sections of group IV showed moderate reaction (Figure 11).

\section{(C) Periodic acid Schiff's reaction (PAS) -Stained sections}

Sections of control and G.T treated animals showed moderate reaction of the matrix, the cytoplasm of proliferating and hypertrophied chondrocytes showed strong to moderate reaction; the metaphyseal bone exhibited a strong reaction (Figure 12). Sections of ethanol treated animals showed mild to moderate reaction of the matrix, chondrocytes and the metaphyseal bone (Figure 13).

\section{(D) Masson's Trichrome (MT)-Stained sections}

Examinationof Masson's trichrome-stained longitudinal sections at the metaphyseal ends of femurs of control rabbits revealed that, bony trabeculae were formed mainly of red staining mineralized matrix and few areas of blue staning unmineralized matrix (osteoid) (Figure 14). Sections of ethanol treated animals showed that, the bony trabeculae were formed mainly of unmineralized bone matrix with few areas of mineralized matrix (Figures 15,16). Sections of group IV revealed more improvement in mineralization of bone matrix (Figure 17).

\section{Morphometric Results}

In comparison to control and GT- treated groups, there was a significant decrease in thickness and number of bone trabeculae, a significant increase in trabecular separation in addition to a significant decrease in osteoblast surface (Ob.S/BS) and a significant increase in osteoclast surface (Oc.S/BS) in ethanol treated rabbits $(p<0.05)$. Green tea supplementation in group IV resulted in significant improvement in all histomorphometric parameters under investigation $(p<0.05)$. (Table 2 and Diagram 1$)$

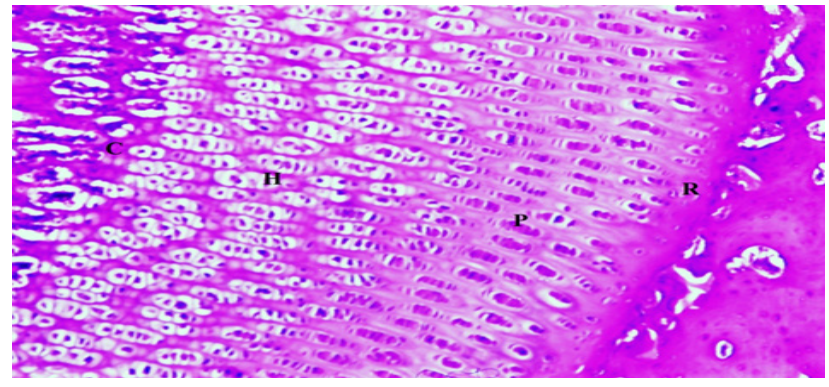

Fig. 2: A photomicrograph of a longitudinal section (LS) in the lower femoral epiphyseal plate from a control rabbit showing different zones of bone growth: resting cartilage $(\mathrm{R})$, proliferation $(\mathrm{P})$, hypertrophy $(\mathrm{H})$, and calcification (C). (H\&E X 100).

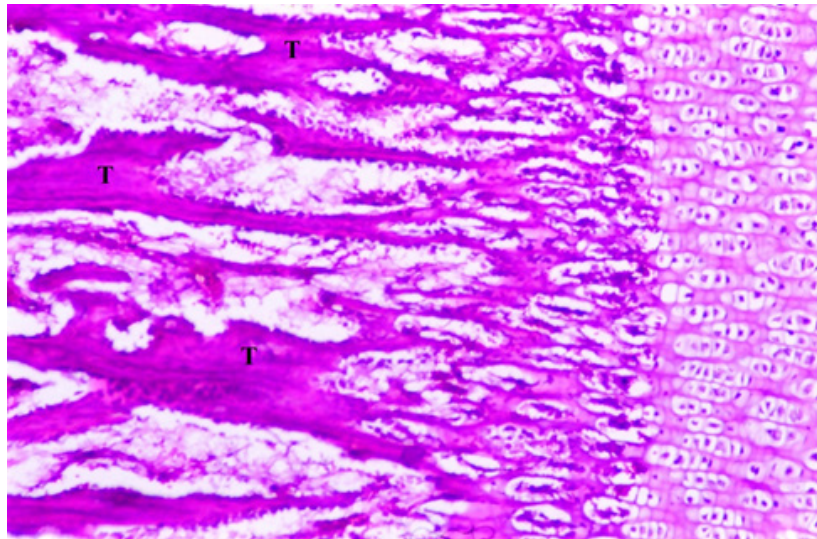

Fig. 3: A photomicrograph of LS in the lower femoral epiphyseal plate of a control rabbit showing long and thick bony trabeculae (T). (H\&E X 100)

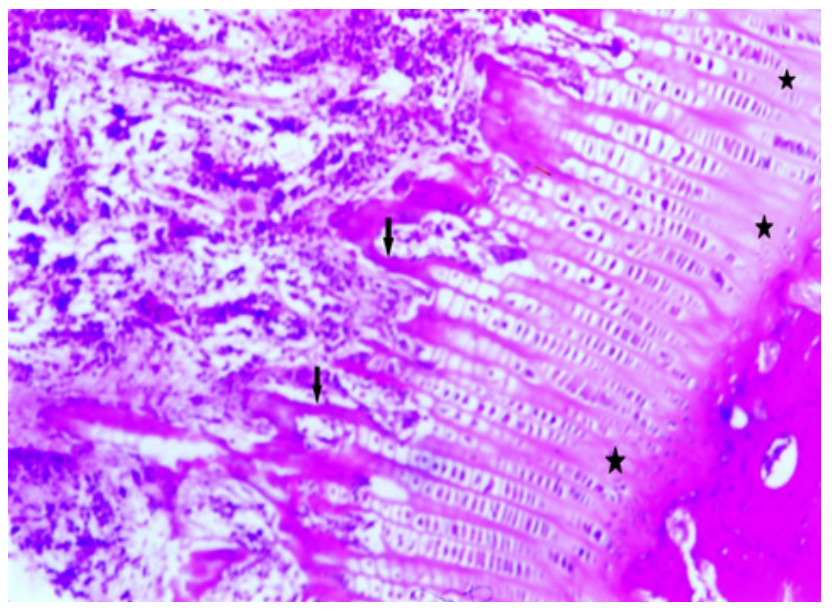

Fig. 4: A photomicrograph of LS in the lower femoral epiphyseal plate from ethanol-treated group (group III) showing thinned cartilaginous plate with apparent decrease in proliferative and hypertrophic zone. Notice: multiple foci of degeneration affecting the proliferative zone (stars). The developing trabeculae are short, thin and few in number (arrows). (H\&E X 100).

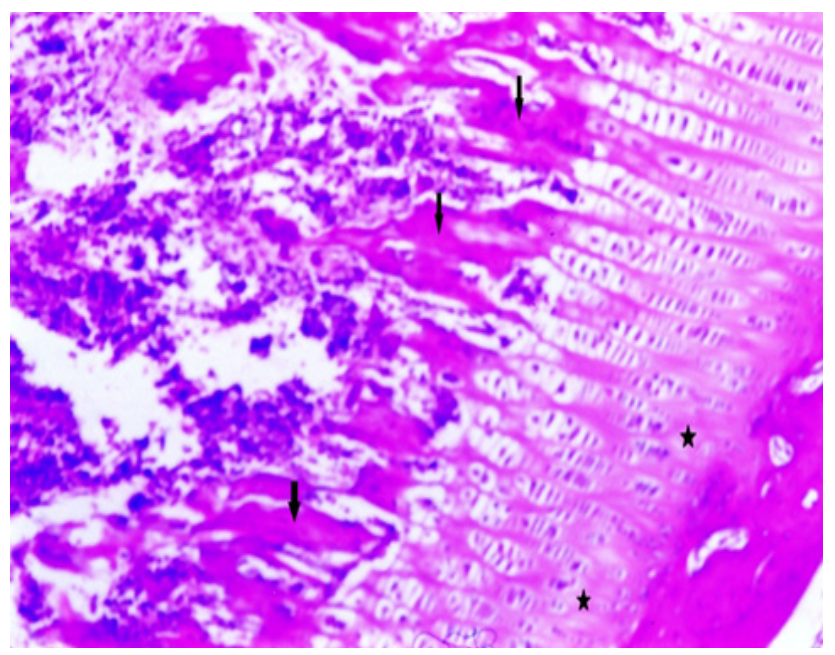

Fig. 5: A photomicrograph of LS in the lower femoral epiphyseal plate of an ethanol and green tea group (group IV) showing that metaphyseal trabeculae are moderate in length, width and number (arrows). Little foci of degeneration in the epiphyseal plate (stars). Notice: The basophilic calcified cartilagenous matrix. (H\&E X 100). 


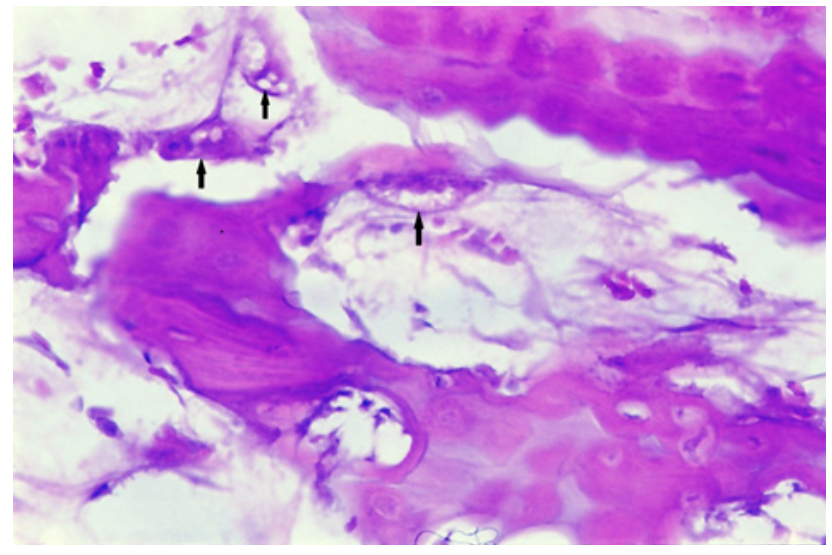

Fig. 6: A photomicrograph of LS in the shaft of the femur from group III showing many osteoclasts in osteolytic cavities (arrows). The cells are large, multinucleated, their cytoplasm is foamy having many vesicles, their brush borders are seen near-by eroded thinned parts of bone. (H\&E $\mathrm{X} 400)$.

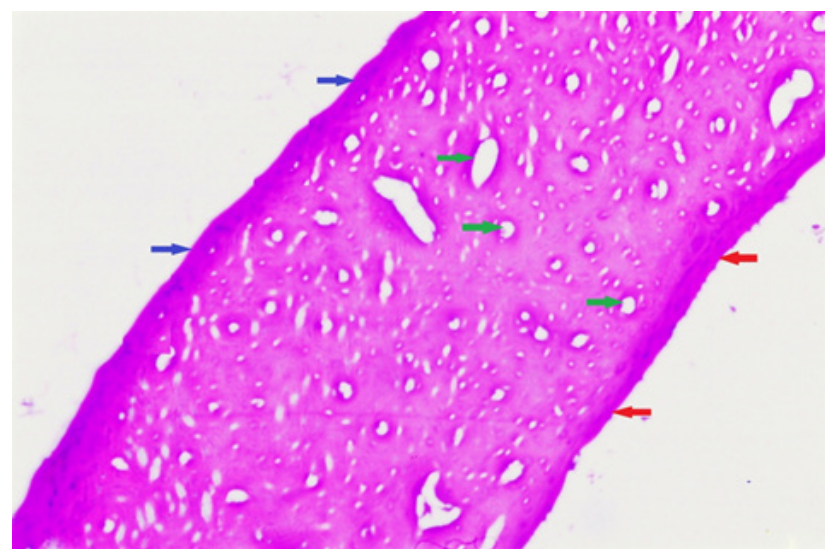

Fig. 7: A photomicrograph of a transverse section (TS) in the diaphysis of the femur of a control rabbit showing many osteons, the center of each is Haversin canal (green arrows). Notice: smooth endosteum (red arrows) and periosteum (blue arrows) (H\&E X 100).

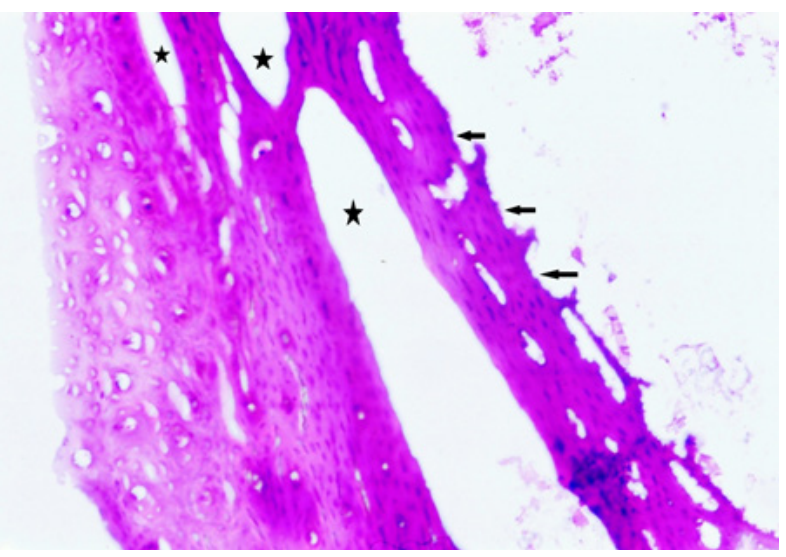

Fig. 8: A photomicrograph of TS in the diaphysis of the femur from group III showing loss of the normal architecture with separated cement lines (stars) and multiple osteoporotic cavities (arrows). (H\&E X 100).

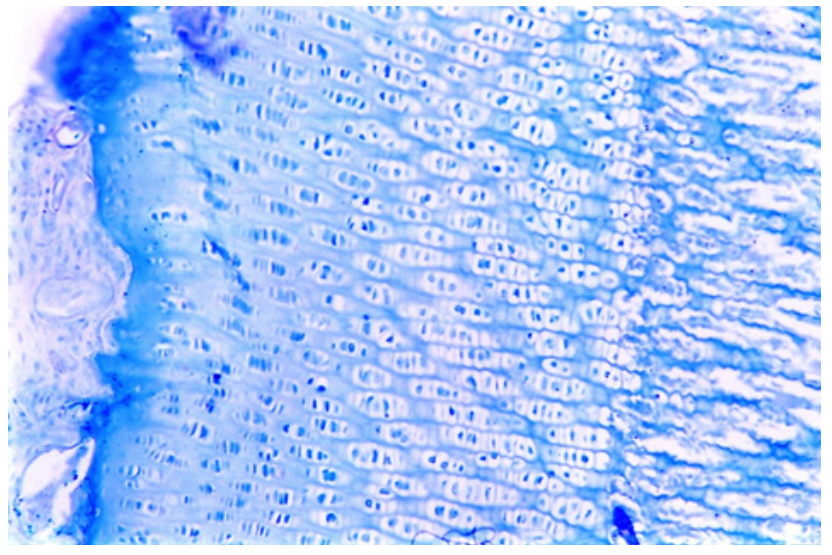

Fig. 9: A photomicrograph of LS in the lower femoral epiphyseal plate of a control rabbit showing dense blue-colored matrix (normal distribution of acid mucopolysaccharides of the matrix) and different zones of bone growth. (AB X 100).

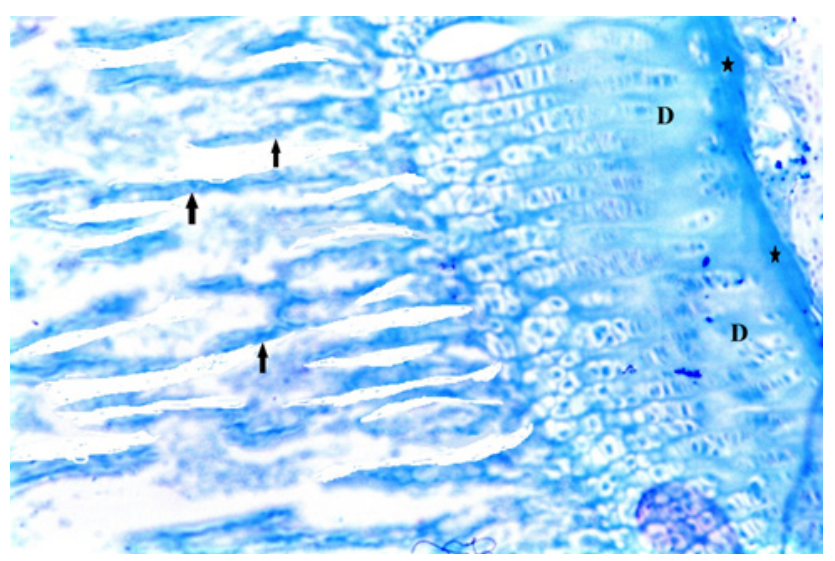

Fig. 10: A photomicrograph of LS in the lower femoral epiphyseal plate from group III showing multiple foci of degeneration (D) affecting the proliferating zone of the thinned cartilaginous plate. The developing trabeculae are short, thin and distorted (arrows). Note the matrix of the resting zone appears turquoise-blue (stars). (A B X 100).

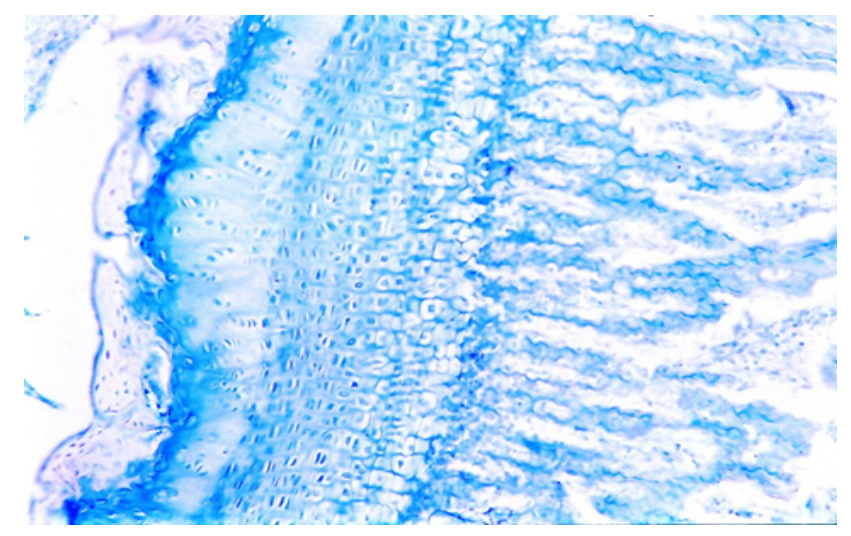

Fig. 11: A photomicrograph of LS in the lower femoral epiphyseal plate from group IV showing that metaphyseal trabeculae became moderate in length, width and number. Little foci of degeneration in the epiphyseal plate. Alcianophilia is moderate. (A B X 100). 


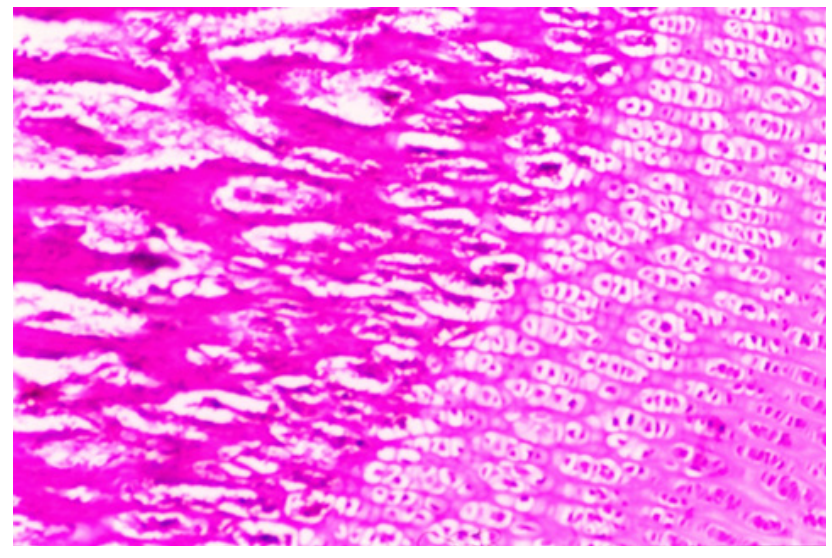

Fig. 12: A photomicrograph of LS in the lower femoral epiphyseal plate of a control rabbit showing moderate reaction of the matrix, the cytoplasm of proliferating and hypertrophied chondrocytes showed strong to moderate reaction; the metaphyseal bone exhibited a strong reaction. (PAS X 100).

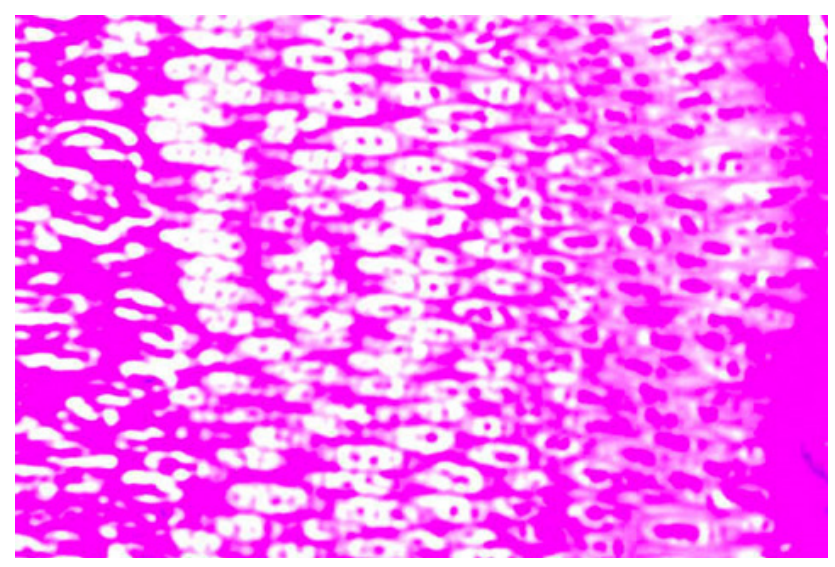

Fig. 13: A photomicrograph of LS in the lower femoral epiphyseal plate from group III showing mild to moderate reaction of the matrix, chondrocytes and the metaphyseal bone. (PAS X 100).

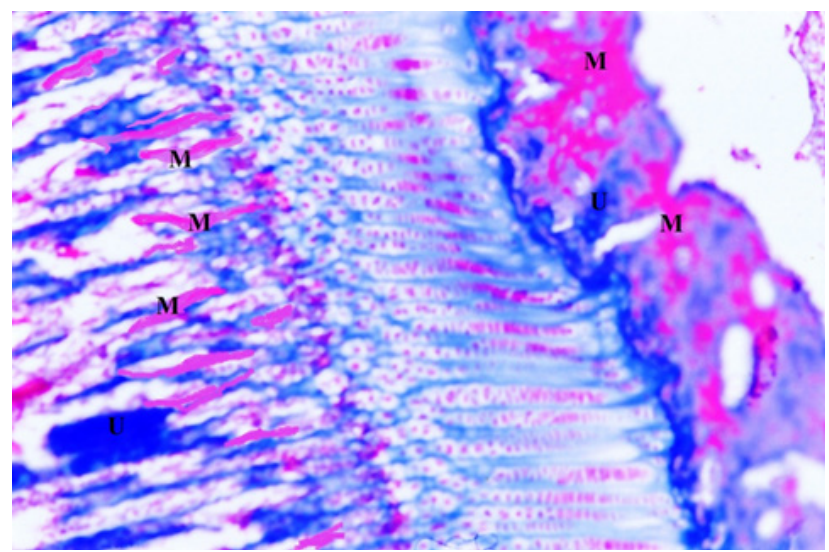

Fig. 14: A photomicrograph of LS in the lower femoral epiphyseal plate of a control rabbits showing that, bony trabeculae were formed mainly of red staining mineralized matrix (M) and few areas of blue staning unmineralized matrix (osteoid) (U). (M.T X 100).

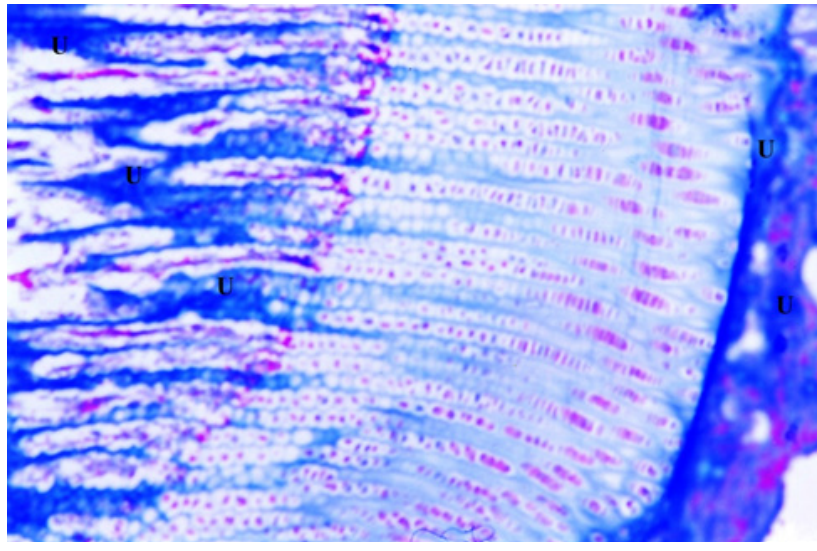

Fig. 15: A photomicrograph of LS in the lower femoral epiphyseal plate from group III showing that the bony trabeculae were formed mainly of unmineralized bone matrix (U) with few areas of mineralized matrix. (M.T X 100).

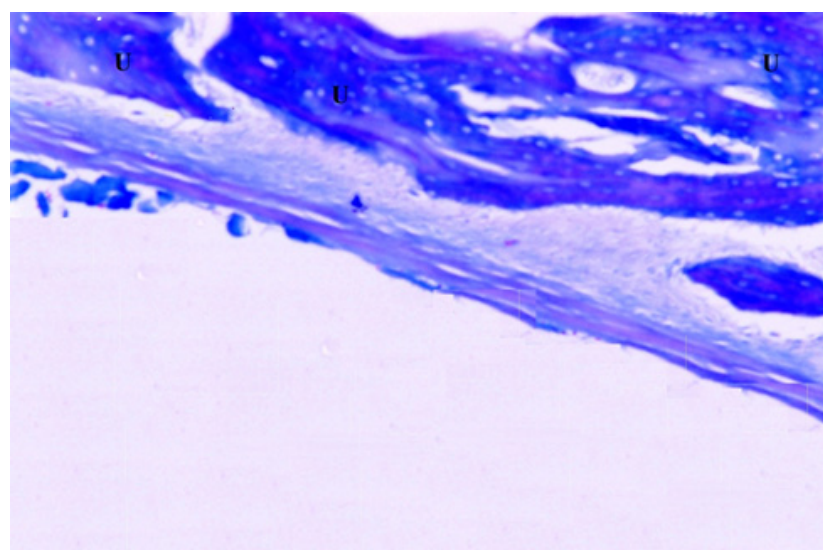

Fig. 16: A photomicrograph of TS in the diaphysis of the femur from group III showing that bone matrix is mainly unmineralized (U). (M.T $\mathrm{X} 100)$.

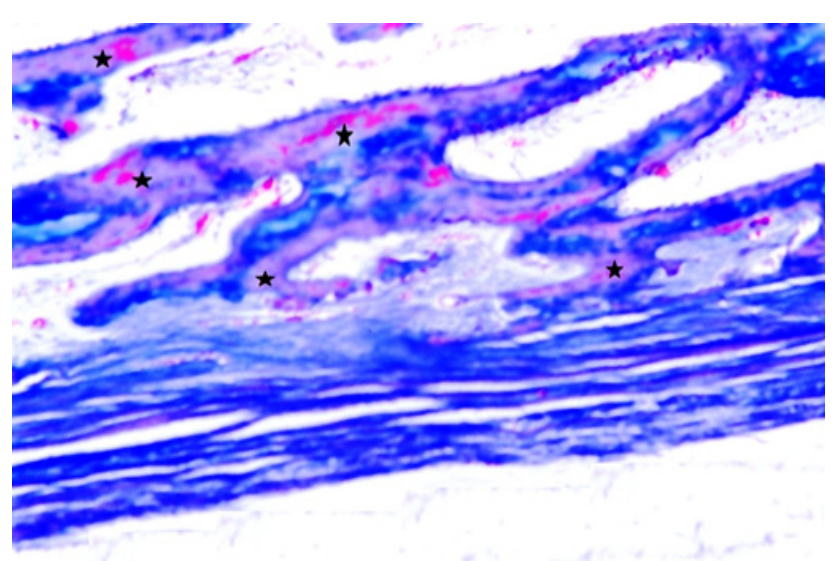

Fig. 17: A photomicrograph of TS in the diaphysis of the femur from group IV showing some areas of mineralization in bone matrix (stars). (M.T X 100). 
Table 1: Values of biochemical parameters in the different studied groups

\begin{tabular}{lcccccc}
\hline & $\mathrm{iCa}(\mathrm{mmol} / \mathrm{L})$ & $\mathrm{P}(\mathrm{mmol} / \mathrm{L})$ & ALP $(\mathrm{mmol} / \mathrm{L})$ & ALT $(\mathrm{U} / \mathrm{L})$ & AST $(\mathrm{U} / \mathrm{L})$ & $\mathrm{Creatinine}(\mu \mathrm{mol} / \mathrm{L})$ \\
\hline Control $(\mathrm{G} \mathrm{I})$ & $2.65 \pm 0.14$ & $2.23 \pm 0.07$ & $1.53 \pm 0.06$ & $38 \pm 4$ & $44 \pm 7$ & $62 \pm 7$ \\
GT (GII) & $2.60 \pm 0.06$ & $2.34 \pm 0.11$ & $1.60 \pm 0.05$ & $36 \pm 4$ & $42 \pm 7$ & $58 \pm 6$ \\
EtOH (GIII) & $2.50 \pm 0.09$ & $2.18 \pm 0.06$ & $1.07 \pm 0.03^{\mathrm{a}, \mathrm{b}}$ & $41 \pm 5$ & $48 \pm 8$ & $60 \pm 7$ \\
EtOH + GT (GIV) & $2.57 \pm 0.04$ & $2.21 \pm 0.05$ & $1.48 \pm 0.07^{\mathrm{c}}$ & $39 \pm 4$ & $43 \pm 6$ \\
\hline
\end{tabular}

GT, green tea group ; EtOH, ethanol-treated group ; EtOH + GT, ethanol and green tea cotreated group. iCa, ionized calcium ; P, phosphorus ; ALP, alkaline phosphatase ; ALT, alanine aminotransferase; AST aspartate aminotransferase.

Data are means $\pm \mathrm{SD}(\mathrm{n}=6$ for each group). Significance at $p<0.05 . \mathrm{a}=$ vs. control, $\mathrm{b}=\mathrm{vs}$. GT-treated group, $\mathrm{c}=\mathrm{vs.} \mathrm{EtOH-treated} \mathrm{group.}$

Table 2: Morphometric values for bone structure, formation and resorption indices in all experimental groups

\begin{tabular}{|c|c|c|c|c|c|}
\hline & Tb.Th & $\mathrm{Tb} . \mathrm{Sp}$ & Tb.N & $\mathrm{Ob} . \mathrm{S} / \mathrm{BS}$ & Oc.S /BS \\
\hline Control (G I) & $58.84 \pm 4.26$ & $285.87 \pm 18.08$ & $4.11 \pm 0.13$ & $8.13 \pm 0.17$ & $2.23 \pm 0.12$ \\
\hline GT (GII) & $56.29 \pm 5.40$ & $294.26 \pm 18.76$ & $3.87 \pm 0.17$ & $8.04 \pm 0.16$ & $2.11 \pm 0.13$ \\
\hline EtOH (GIII) & $38.80 \pm 6.25^{\mathrm{a}, \mathrm{b}}$ & $347.74 \pm 15.65^{\mathrm{a}, \mathrm{b}}$ & $3.58 \pm 0.29^{\mathrm{a}, \mathrm{b}}$ & $5.24 \pm 0.16^{\mathrm{a}, \mathrm{b}}$ & $3.93 \pm 0.15^{\mathrm{a}, \mathrm{b}}$ \\
\hline EtOH + GT (GIV) & $52.81 \pm 5.19^{c}$ & $273.88 \pm 17.33^{\mathrm{c}}$ & $3.8 \pm 0.15^{\mathrm{c}}$ & $7.78 \pm 0.39^{c}$ & $2.30 \pm 0.21^{\mathrm{c}}$ \\
\hline
\end{tabular}

Tb.Th, thickness of trabeculae in micrometers; Tb.Sp, trabecular separation in micrometers ; Tb.N, number of trabeculae /mm; Ob.S/BS, osteoblast surface per bone surface ; Oc.S/BS, osteoclast surface per bone surface.

Data are mean $\pm \mathrm{SD}$ ( $\mathrm{n}=6$ for each group). Significance at $p<0.05 . \mathrm{a}=\mathrm{vs}$. control, $\mathrm{b}=\mathrm{vs}$. GT-treated group, $\mathrm{c}=\mathrm{vs}$. EtOH-treated group.

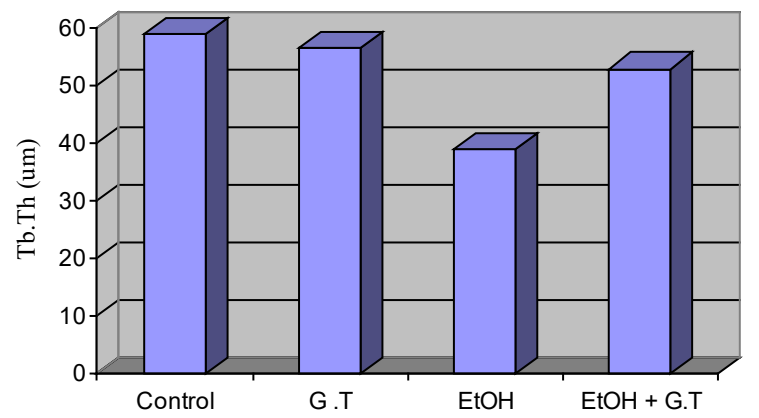

Diagram (1,A): Trabecular thickness (um) in all experimental groups.

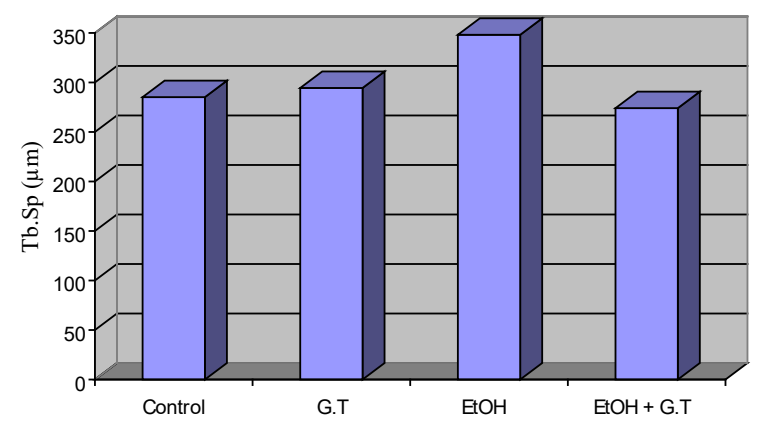

Diagram (1,B): Trabecular separation (um) in all experimental groups.

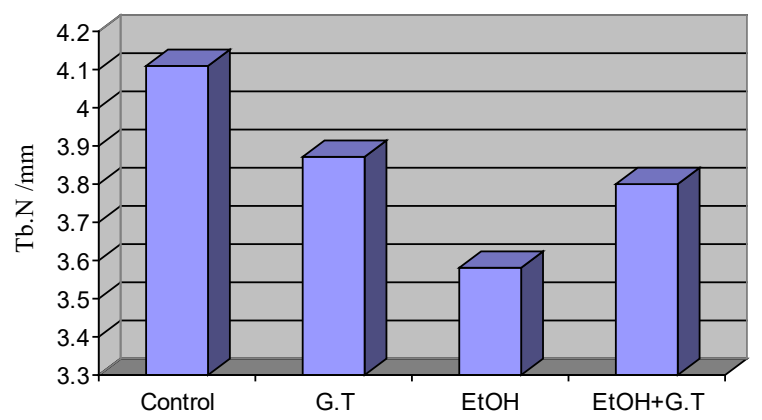

Diagram (1,C): Trabecular number / $\mathrm{mm}$ in all experimental groups.

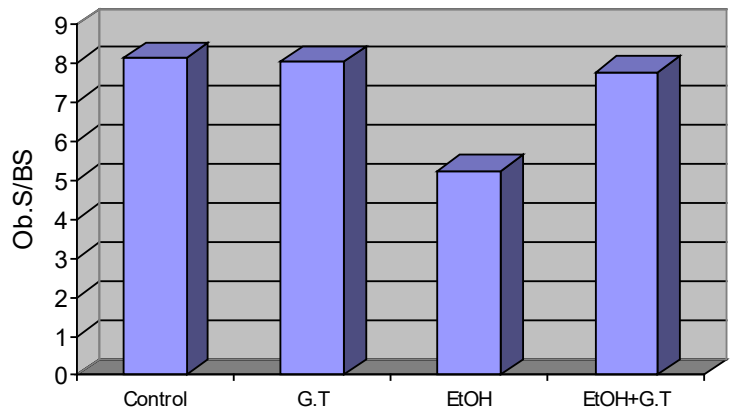

Diagram (1,D): Osteoblast surface/BS in all experimental groups.

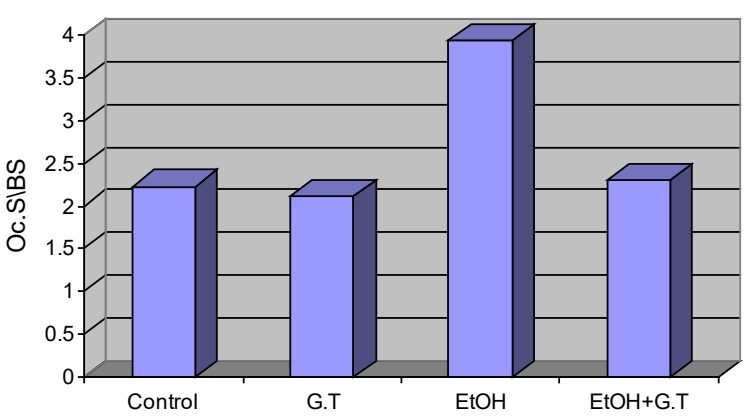

Diagram (1,E): Osteoclast surface/ BS in all experimental groups.

\section{DISCUSSION}

Chronic alcohol consumption decreases bone mass, inhibits differentiation and function of osteoblasts, increases incidence of fracture and delays its healing ${ }^{[26,27]}$. It can result in osteopenia ${ }^{[28,29]}$ and osteoporosis ${ }^{[0,30]}$. This study was performed to investigate the hazardous effects of ethanol on bone and the possible ameliorating role of GTE.

The results from our study demonstrate that chronic alcohol consumption resulted in an insignificant decrease in serum ionized calcium and a significant decrease in serum 
alkaline phosphatase. These results are partially compatible with the other remarks that chronic alcohol abusers have low plasma levels of calcium ${ }^{[25,31]}$. Hypocalcemia in chronic alcohol abusers is due to hypomagnesaemia which was found in $30 \%$ of patients by lowering renal tubular reabsorption. Hypomagnesaemia leads to inhibition of parathyroid hormone secretion, parathyroid hormone resistance and vitamin D suppression and consequently, causing hypocalcaemia ${ }^{[31]}$.

In accordance with the present work, many studies revealed that serum activity of alkaline phosphatase in chronic alcohol abusers was decreased ${ }^{[32]}$. This was explained by depression of bone formation after alcohol ingestion ${ }^{[33]}$. Our results, also, revealed the occurrence of insignificant change in the level of serum phosphorus which in agreement with previous studies such $\mathrm{as}^{[34]}$. On the same side, serum activities of ALT and AST, and creatinine level in Ethanol-treated rabbits did not differ from those of the controls indicating that ethanol administration did not result in hepatic or renal damage which can affect the bone.

The biochemical findings are assured from histopathological changes noticed in the current study which revealed that longitudinal sections in the lower femoral epiphyseal plates of ethanol treated animals showed multiple areas of degeneration at the proliferating and hypertrophied zones of the thinned cartilaginous plate. These findings are consistent with other studies which showed slight epiphyseal growth and proliferation of chondrocytes, which are important in bone development ${ }^{[35]}$. These cells will deposit extracellular matrix that will be invaded by osteoblasts to form new bone, resulting in arrest of longitudinal growth of bone ${ }^{[36]}$.

The developing trabeculae were thinner, shorter and fewer in number in comparison to those from control rabbits. These results coincide with our morphometric measurements that showed significant decrease in thickness and number of bone trabeculae and significant increase in trabecular separation. Such findings pass in hand with the result of SEM of the distal end of the femur which showed that the bone trabeculae from ethanol-treated rabbits were thinner than those from controls ${ }^{[37]}$. High levels of alcohol consumption can result in trabecular thinning due to imbalance between bone formation and resorption ${ }^{[8]}$.

The mechanism that alcohol consumption increases osteoporosis, bone fractures and inhibits its repair remains indistinct $^{[38]}$. However, alcohol enhances osteoporosis by modulation of the production and resorption arms of bone remodeling ${ }^{[39]}$. Ethanol incited osteopenia is due to an immediate impact of ethanol on bone cells and a backhanded impact through mineral-managing hormones as parathyroid hormone, calcitonin and nutrient D metabolites $^{[8]}$

Moreover, alcohol -incited bone loss in rats is mainly due to activation of osteoclasts ${ }^{[28]}$. However, there was no significant difference in femoral osteoclasts in EtOH-treated hamsters compared with controls ${ }^{[37]}$. Our study demonstrates that ethanol induces bone resorption as evidenced by the presence of many osteoclasts and multiple resorption cavities in sections of ethanol treated animals. Also, in histomorphometric results there was significant increase in Oc.S/BS and in Tb.Sp. Then again; there was noteworthy lessening in Tb.Th and number in the ethanol treated rabbits. These results are consistent with the morphometric study which showed increase in resorptive surface and number of osteoclasts in alcohol abusers. In addition, there was decreased trabecular width, increased their spacing and increased osteoclast surface in femurs of EtOH- treated animals ${ }^{[39]}$.

Ethanol-initiated osteopenia results mostly from diminished bone formation as opposed to enhanced bone resorption ${ }^{[9,29]}$. Alcohol consumption suppresses the function of osteoblasts, as evidenced by low serum level of osteocalcin and it causes osteocytes apoptosis ${ }^{[40]}$, and decrease several osteoblastic parameters ${ }^{[39]}$. These findings pass in line with our results as there was significant decrease in Ob.S/BS. Alcohol alters osteoblast gene expression and matrix synthesis ${ }^{[4]}$. Persistent alcohol utilization inhibits differentiation of osteoblasts from bone marrow cells into and enhances adipogenesis ${ }^{[29,32]}$. Moreover, ethanol consumption may have harmful impacts on bone vasculature. It inhibits angiogenesis which is compulsory for bone formation and it cause deposition of triglycerides and cholesterol in blood vessles ${ }^{[42,43]}$. Alcohol consumption increase calcitonin level ${ }^{[44]}$ and decrease leptin hormone which has anabolic effect on bone ${ }^{[45]}$.

In our study, Alcian blue stained sections of control and green tea treated rabbits showed dense blue colored matrix owing to normal distribution of acid mucopolysaccharide, while ethanol treated animals showed deceased alcianophilia which could be due to degenerative changes in the proliferating zone of the cartilaginous plates. Alcianophilia was improved in protected animals.

PAS staining of sections from ethanol treated rabbits indicated decreased PAS reaction of matrix, chondrocytes and the metaphyseal bone due to decrease neutral mucopolysaccharides and glycoproteins content in new bone and calcifying cartilage and decrease glycogen in some early osteoblasts.

Masson's Trichrome-stained sections of ethanol treated rabbits showed that bony trabeculae were formed mostly of unmineralized bone matrix with few areas of mineralized matrix. This was attributed to depression of bone formation activity after alcohol exposure. Direct inhibitory impacts of ethanol on osteoblast proliferation have been accounted for in vivo and in vitro ${ }^{[46]}$ Using Masson's Trichrome stain, experimental studies revealed that old mineralized trabecular bone and new unmineralized bone were stained red and blue, respectively ${ }^{[47]}$.

In the present study on the possible protective role of green tea on bone, the biochemical, histological and morphometrical results showed improved picture than that of ethanol treated rabbits. The next studies 
judged the present results. Green tea enhances bone health through diminishing oxidative stress, enhancing antioxidant enzymes activity and diminishing expression of proinflammatory mediators ${ }^{[48,49]}$ It was reported that Oxidative stress leads to enhancing osteoblast and osteocyte apoptosis and diminishing differentiation of osteoblasts $^{[50,51]}$. Reactive oxygen species (ROS) are associated with the procedure of bone resorption with an immediate involvement of osteoclast-generated superoxide to bone debasement. Also, oxidative stress enhances osteoclastic functions and differentiation ${ }^{[52]}$.

It worth mention that a study indicated that catechin caused an important enhancement of osteoblastic existence and proliferation in addition to a reduction in osteoblastic apoptosis. Epigallocatechin gallate (EGCG), a type of catechin can enhance osteoblastogenesis via a mechanism mediated by the vascular endothelial growth factor ${ }^{[33]}$.

Additionally, a study revealed that catechin suppressed the advancement of bone resorption ${ }^{[54]}$. Furthermore, different investigations have shown that EGCG significantly inhibited osteoclastic differentiation and functions ${ }^{[55,56]}$ and increased their apoptosis ${ }^{[57]}$.

GT enhances osteoclastic apoptosis through caspase activation-dependent mechanisms ${ }^{[58]}$. On a similar side, EGCG can inhibit bone resorption by suppressing IL-6 creation by osteoblasts whereby IL-6 stimulates osteoclastogenesis and bone resorption ${ }^{[59]}$.

The main organic component of the bone matrix is collagen. Degradation of collagen by collagenase is an important step in bone resorption ${ }^{[60]}$. So, increased collagen resistance to collagenase can reduces bone resorption. Catechin inhibits bone resorption and prevents osteoclastic function through preservation of bone collagen ${ }^{[54]}$. Tea is likewise a significant wellspring of phytoestrogen and fluoride, they may help to preserve bone mineral density and alleviate osteoporosis ${ }^{[61]}$.

\section{CONCLUSION}

It was clear that chronic alcohol consumption induces bone loss and osteoporosis, so it is recommended to restrict its consumption. These bone changes could be ameliorated by natural products such as green tea which is fairly cheap, simple and easily available. Green tea consumption should be encouraged especially in people subjected to bone alterations.

\section{CONFLICT OF INTERESTS}

There are no conflicts of interest.

\section{REFERENCES}

1. Schuckit MA: Alcohol-use disorders. Lancet. (2009) 373: 492-501.

2. Olszynski WP, Shawn Davison K, Adachi JD, et al:: Osteoporosis in men: epi-demiology, diagnosis, prevention, and treatment. Clin Ther. (2004) 26: 15-28.
3. Chakkalakal DA, Novak JR and Fritz ED: Inhibition of bone repair in a rat model for chronic and excessive alcohol consumption. Alcohol. (2005) 36(3): 201-214.

4. Richards CJ, Graf KW Jr, Mashru RP: The Effect of Opioids, Alcohol, and Nonsteroidal Anti-inflammatory Drugs on Fracture Union. Orthop Clin North Am. (2017) 48(4): 433-443.

5. Cheung RC, Gray C, Boyde A and Jones SJ: Effects of ethanol on bone cells in vitro resulting in increased resorption. Bone. (1995)16:143-147.

6. Rapuri PB, Gallagher JC, Balhorn KE, Ryschon KL: Alcohol intake and bone metabolism in elderly women. Am J Clin Nutr. (2000) 72(5):1206-1213.

7. Keiver K, Weinberg J: Effect of duration of alcohol consumption on calcium and bone metabolism during pregnancy in the rat. Alcohol Clin Exp Res. (2003) 27(9): 1507-1519.

8. Turner RT, Kidder LS, KennedyA, Evans GL and Sibonga JD: Moderate alcohol consumption suppresses bone turnover in adult female rats. J. Bone Miner. Res. (2001)16(3): 589-594.

9. Sampson HW: Alcohol and other factors affecting osteoporosis risk in women. Alcohol Res. Health. (2002) 26(4):292-298

10. Turner RT: Skeletal response to alcohol. Alcohol Clin. Exp. Res. (2000) 24:1693-1701.

11. Hogan HA, Argueta F, Moe L, Nguyen LP and Sampson HW: Adult-onset alcohol consumption induces osteopenia in female rats. Alcohol Clin. Exp. Res. (2001) 25: 746-754

12. Simpson ME, Duggal S and Keiver K: Prenatal ethanol exposure has differential effects on fetal growth and skeletal ossification. Bone. (2005)36(3): 521-532.

13. Cabrera C, Artacho R, and Giménez R: Beneficial Effects of Green Tea-A Review. J Am Coll Nutr. (2006) 25(2): 79-99.

14. Chen D, Milacic V, Chen MS, Wan SB, Lam WH, Huo C, Landis-Piwowar KR, Cui QC, Wali A, Chan TH, and Dou QP: Tea polyphenols, their biological effects and potential molecular targets. Histol. Histopathol. (2008) 23(4): 487-496.

15. McKay DL and Blumberg JB: The role of tea in human health: An update. J Am Coll Nutr. (2002) $21: 1-13$

16. Wu CD and Wei GX: Tea as a functional food for oral health. Nutrition (2002) $18: 443-444$.

17. Yang CS, Landau JM. Effects of tea consumption on nutrition and health. J Nutr (2000)130:2409-2412. 
18. Hegarty VM, May HM and Khaw KT: Tea drinking and bone mineral density in older women. Am. J. Clin. Nutr. (2000)71: 1003-1007.

19. Wu CH, Yang YC and Yao WJ: Epidemiological evidence of increased bone mineral density in habitual tea drinkers. Arch. Intern. Med. (2002) 162:1001-1006.

20. Maity S, Vadasiromoni J and Ganguly D: Role of glutathione in the antiulcer effect of hot water extract of black tea. Jpn. J. Pharmacol. (1998)78: 285-292.

21. Martinez M, Milton FA, de Oliveira SA, de Lima NF, Segatelli TM, Pinheiro PF, Almeida CC, Mello W Jr, Quitete VH, Martinez FE : Ultrastructural changes on the hard palatine mucosa of Calomys callosus after 120 days of experimental chronic alcoholism. J Submicrosc Cytol Pathol. (2005) 37(1): 59-65.

22. Bancroft JD, Layton $\mathrm{C}$ and Suvarna K: Theory and Practice of Histological Techniques. $7^{\text {th }}$ ed., Churchill Livingstone, NewYork, Edinburgh, London. (2013) p.199-202, 221-225 and p.325.

23. Kiernan JA: Histologic and histochemical methods: Theory and practice. $3^{\text {rd }}$ edition. Arnold publisher, London, New York and New Delhi (2001) p.111-162.

24. Bishop ML, Fody EP, Larry E and Schoeff LE: Bishop clinical chemistry. $7^{\text {th }}$ edition. Philadelphia : Wolters Kluwer Health/Hippincott Williams and Wilkins. (2010) p 225-232.

25. Keiver K, Duggal S and Simpson M E: Ethanol administration results in a prolonged decrease in blood ionized calcium levels in the rat. Alcohol. (2005) 37(3):173-178.

26. Gaddini GW, Turner RT, Grant KA, Iwaniec UT. Alcohol: A Simple Nutrient with Complex Actions on Bone in the Adult Skeleton. Alcohol Clin Exp Res. 2016;40(4):657-671.

27. Brown EC, Perrien DS, Fletcher TW, Irby DJ, Aronson J, Gao GG, Hogue WJ, Skinner RA, Suva LJ, Ronis MJ, Hakkak R, Badger TM, Charles K and Lumpkin CK : Skeletal Toxicity Associated with Chronic Ethanol Exposure in a Rat Model Using Total Enteral Nutrition. Pharm.and Exp. Ther. (2002) 301(3): 1132-1138.

28. Shankar K, Hidestrand M, Haley R, Skinner R, Hogue W, Jo C, Simpson P, Lumpkin CK, Aronson J, Badger TM and Ronis MJ: Different Molecular Mechanisms Underlie Ethanol-Induced Bone Loss in Cycling and Pregnant Rats. Endocrinology. (2006) 147(1): 166-178.

29. Chakkalakal DA: Alcohol-induced bone loss and deficient bone repair. Alcohol Clin. Exp. Res. (2005) 29 (12): 2077-2090.
30. Gonzalez-Reimers E, Duran-Castellon MC, Martin-Olivera R, Lopez-Lirola A, Santolaria-Fernandez F, De la Vega-Prieto MJ, Perez-Ramirez A and Garcia-Valdecasas Campelo E: Effect of zinc supplementation on ethanol-mediated bone alterations. Food Chem. Toxicol. (2005) 43(10):1497-1505.

31. Smets YF, Bokani N, de Meijer PH and Meinders AE: Tetany due to excessive use of alcohol: a possible magnesium deficiency.Ned Tijdschr Geneeskd. (2004)148(14): 641-644.

32. Yisheng W, Li Y, Yuebai L, Peilin L and Quanjun C: Preventive Effects of Puerarin on Alcohol-induced Osteonecrosis. Clin. Orthop. Relat. Res. (2008) 466(5): 1059-1067.

33. John J C, Ryan H, Kristen L, Frederick H W, and Kirstyn B: Binge Alcohol-Induced Bone Damage is Accompanied by Differential Expression of Bone Remodeling-Related Genes in Rat Vertebral Bone. Calcif Tissue Int. (2009) 84 (6): 474-484.

34. Pumarino H, González P, Oviedo S, Lillo R and Bustamante $\mathrm{E}$ : Assessment of bone status in intermittent and continuous alcoholics, without evidence of liver damage. Rev. Med. Chil. (1996) 124 (4):423-430.

35. Chakkalakal DA, Novak JR, Fritz ED, Mollner TJ, McVicker DL, Lybarger DL, McGuire MH and Donohue JT: Chronic ethanol consumption results in deficient bone repair in rats. Alcohol Alcohol (2002) 37:13-20.

36. De Crombrugghe B, Lefebvre V and Nakashima $\mathrm{K}$ : Regulatory mechanisms in the pathways of cartilage and bone formation. Curr Opin Cell Biol (2001) 13: 721-727.

37. Chen H, Hayakawa D, Emura S, OzawaY, Taguchi $\mathrm{H}$, Yano R and Shoumura S: Effects of ethanol on the ultrastructure of the hamster femur. Histol Histopathol. (2001) 16 (3):763-770

38. Bourrin S, Ammann P, Bonjour JP and Rizzoli $\mathrm{R}$ : Dietary protein restriction lowers plasma insulin-like growth factor I (IGF-I), impairs cortical bone formation, and induces osteoblastic resistance to IGF-I in adult female rats. Endocrinology (2000) 141: 3149-3155.

39. Dai C, Lin D, Zhang J, Habib P, Smith P, Murtha J, Fu Z, Yao Z, Qi Y and Keller ET: Alcohol ingestion induces osteoclastogenesis and bone loss through IL-6 in mice. J. Clin. Invest. (2000) 106(7): 887-895.

40. Santori C, Ceccanti M, Diacinti D, Attilia ML, Toppo L, D'Erasmo E, Romagnoli E, Mascia ML, Cipriani C, Prastaro A, Carnevale V and Minisola $\mathrm{S}$ :Skeletal turnover, bone mineral density, and fractures in male chronic abusers of alcohol. J. Endocrinol. Invest. (2008) 31(4):321-326. 
41. Wezeman FH, Emanuele MA, Emanuele NV, Moskal SF, Woods M, Suri M, Steiner J and LaPaglia N: Chronic alcohol consumption during male rat adolescence impairs skeletal development through effects on osteoblast gene expression, bone mineral density, and bone strength. Alcohol Clin. Exp. Res. (1999) 23(9):1534-1542.

42. Kraszpulski M, Tukaj C and Wrzolkowa $\mathrm{T}$ : Hippocampal capillaries in different age groups of chronically ethanol-intoxicated rats. Morphometrical studies. Folia Morphol (Warsz) (2000) 59: 121-129.

43. Mariann R. Piano : Alcohol's Effects on the Cardiovascular System. Alcohol Res. (2017) 38(2): 219-241.

44. Vantyghem MC, Danel T, Marcelli-Tourvieille S, Moriau J, Leclerc L, Cardot-Bauters C, Docao C, Carnaille B, Wemeau JL, and D'Herbomez M: Calcitonin Levels Do Not Decrease with Weaning in Chronic Alcoholism. Thyroid (2007) 17(3): 213-217.

45. Röjdmark S1, Calissendorff J, Brismar K: Alcohol ingestion decreases both diurnal and nocturnal secretion of leptin in healthy individuals. Clin Endocrinol (Oxf). (2001) 55(5):639-647.

46. Aguado F, Revilla M, Hernandez ER, Menendez M, Cortes-Prieto J, Villa LF and Rico H: Ultrasonographic bone velocity in pregnancy: a longitudinal study. Am J Obstet Gynecol (1998) 178: 1016-1021.

47. Han X, Du J, Liu D, Liu H, Amizuka N, and Li M: Histochemical examination of systemic administration of eldecalcitol combined with guided bone regeneration for bone defect restoration in rats. J Mol Hist. (2017) 48: 41-51

48. Shen CL, Wang P, Guerrieri J, Yeh J, Wang JS. Protective effect of green tea polyphenols on bone loss in middle-aged female rats. Osteoporosis Int (2008)19 (7): 979-990.

49. Adak M and Gabar MA: Green tea as a functional food for better health: A brief review. Research Journal of Pharmaceutical, Biological and Chemical Sciences. (2011) 2(2): 645-664.

50. Manolagas SC. De-fense! De-fense! De-fense: scavenging $\mathrm{H} 2 \mathrm{O} 2$ while making cholesterol. Endocrinology (2008)149(7): 3264-3276.
51. Fatokun AA, Stone TW, Smith RA. Responses of differentiated MC3T3-E1 osteoblast-like cells to reactive oxygen species. Eur J Pharmacol (2008) 587(1-3): 35-41.

52. Sontakke AN, Tare RS. A duality in the roles of reactive oxygen species with respect to bone metabolism. Clin Chim Acta (2002) 318(1-2):145-158.

53. Choi EM, Hwang JK. Effects of (+)-catechin on the function of osteoblastic cells. Biol Pharm Bull (2003) 26(4): 523-536.

54. Shen CL, Yeh JK., Cao J and Wang JS: Green Tea and Bone metabolism. Nutr Res. (2009) 29(7): 437-456.

55. Yun JH, Pang EK, Kim CS, Yoo YJ, Cho KS, Chai JK, et al. Inhibitory effects of green tea polyphenol(-)-epigallocatechin gallate on the expression of matrix metalloproteinase- 9 and on the formation of osteoclasts. J Periodontal Res (2004) 39(5): 300-307.

56. Lin RW, Chen $\mathrm{CH}$, Wang $\mathrm{YH}$, Ho ML, Hung $\mathrm{SH}$, Chen IS, et al. Epigallocatechin gallate inhibition of osteoclastic differentiation via NF-kappaB. Biochem Biophys Res Commun. (2009) 379(4):1033-1047

57. Hafeez BB, Ahmed S, Wang N, Gupta S, Zhang A, Haqqi TM. Green tea polyphenols-induced apoptosis in human osteosarcoma SAOS-2 cells involves a caspase-dependent mechanism with down regulation of nuclear factor-kappaB. Toxicol Appl Pharmacol (2006) 216(1):11-19.

58. Grütter MG. Caspases: key players in programmed cell death. Curr Opin Struct Biol (2000)10(6): 649-655.

59. Blair HC, Robinson LJ, Zaidi M. Osteoclast signalling pathways. Biochem Biophys Res Commun (2005) 328(3):728-738.

60. Clarke B. Normal bone anatomy and physiology. Clin J Am Soc Nephrol (2008) 3(3):131-139.

61. Chen Z, Pettinger MB, Ritenbaugh C, LaCroix AZ, Robbins J, Caan BJ, Barad DH and Hakim IA: Habitual Tea Consumption and Risk of Osteoporosis: A Prospective Study in the Women's Health Initiative Observational Cohort. Am. J. Epidem. (2003) 158 (8): 772-781. 


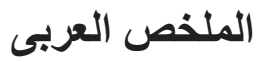

\section{الدور الوقائي للشاي الأخضر ضد التغيرات التى تحدث لعظام الأرانب الذكور البالغة بواسطة الإيثانول: دراسة كيميائية حيوية ، نسيجية ومورفومترية \\ حازم وهاب"، ، رمضان الامهوجى'، نهال المخدمّ، محمد عبد الجبار؛ \\ 'قسم الهستولوجيا، كلية الطب، جامعة المنوفية \\ بقسم الهستولوجيا، بقسم الباثولوجيا الاكلينيكية، كلية الطب، جامعة الجوف \\ ؛قسم الكيمياء الحيوية، كلية العلوم، جامعة بنى سويف}

خلفية الموضوع: تعاطي الكحول المزمن هو اضطر اب سريري و اسع النطاق. و يؤدي إلى تغير ات بالعظام ، وخاصة

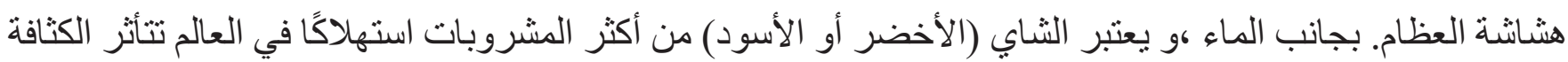
المعدنية للعظام بالعديد من المركبات الموجودة في مستخلصات البات الثنابي.

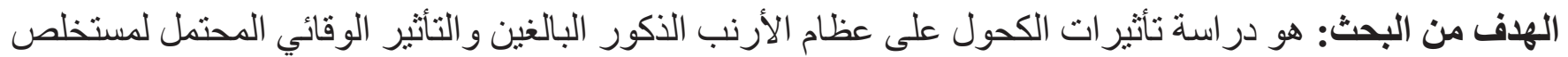
الثاي الأخضر. المواد والطرق: تم استخدام أربعة وعشرين من الأرانب الذكور البالغين وتم تقسيمهم إلى ؛ مجموعات متساوية.

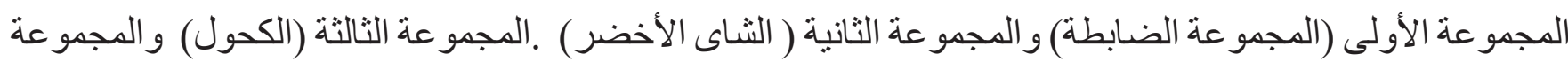
الر ابعة (الكحول و الثاى الأخضر) . بعد • r ( يوم من العلاج تم تخدير جميع الحيو انات وذبحها. تم فياس نسب الكحول

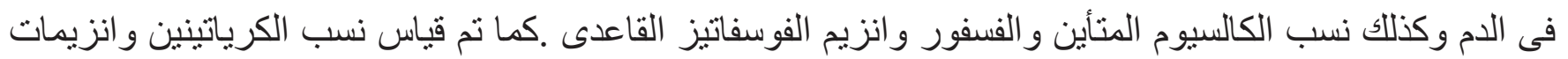
الأمينو ألانين الناقل و والأمينو أسبرتات الناقل لتحديد سلامة الكلى والكبد .تم تشريح عظام الفخد و اعدادها للار اسة النسيجية و المورفومترية. النتائج: وجد أن التعاطى المزن للكحول أدى الى قلة غير معتد بها احصائيا فى مستوى الكالسيوم المتأين و الى قلة معتد

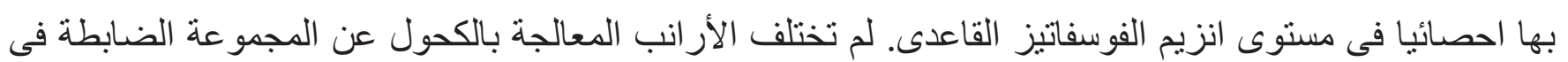

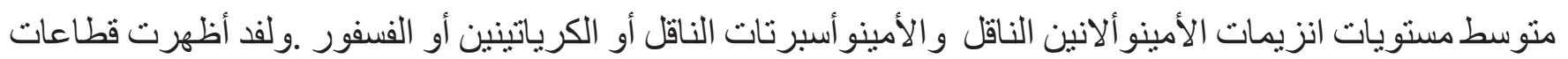
من عظام الأر انب المعالجة بالكحول وجود مناطق تحلل عديدة في الصحيفة الغضروفية الرفيعة كما أن التر ابيق كانت رفيعة وقصيرة وقليلة فى العدد عن مثنيلاتها فى المجمو عة الضابطة. وقد أدى العلاج بالكحول الى قلة معتد سطح الخلايا البنائية للعظام وزيادة معتد بها فى سطح الخلايا الناقضة للعظام. تناول الثاى الأخضر أدى الى تحسن شديد في صورة صورة العظم النسيجية ومعظم القياسات تحت الفحص. الخلاصة: مما سبق يتضح وجود نأثير ات خطيرة للكحول على العظم لذلك من الأفضل أن يقل تناوله ـ. المنتجات الطبيعية كالثاى الأخضر قادرة على الحماية من تدهور العظام. 